\title{
Involvement of oxidative stress and mucosal addressin cell adhesion molecule-1 (MAdCAM-1) in inflammatory bowel disease
}

\author{
Satoshi Tanida, ${ }^{1, *}$ Tsutomu Mizoshita, ${ }^{1}$ Takashi Mizushima, ${ }^{1}$ Makoto Sasaki,, Takaya Shimura, ${ }^{1}$ Takeshi Kamiya, \\ Hiromi Kataoka' and Takashi Joh ${ }^{1}$ \\ 'Department of Gastroenterology and Metabolism, Graduate School of Medical Sciences, Nagoya City University, \\ 1 Kawasumi, Mizuho, Nagoya, Aichi 467-8601, Japan \\ ${ }^{2}$ Department of Gastroenterology, Aichi Medical University School of Medicine, 21 Karimata, Yazako, Nagakute-cho, Aichi 480-1195, Japan
}

(Received 20 April, 2010; Accepted 1 June, 2010; Published online 26 February, 2011)

\begin{abstract}
The pathophysiology of inflammatory bowel disease involves excessive immune effects of inflammatory cells against gut microbes. In genetically predisposed individuals, these effects are considered to contribute to the initiation and perpetuation of mucosal injury. Oxidative stress is a fundamental tissue-destructive mechanisms that can occur due to the reactive oxygen species and reactive nitrogen metabolites which are released in abundance from numerous inflammatory cells that have extravasated from lymphatics and blood vessels to the lamina propria. This extravasation is mediated by interactions between adhesion molecules including mucosal addressin cell adhesion molecule- 1 and vascular cell adhesion molecule-1 on the surface of lymphocytes or neutrophils and their ligands on endothelial cells. Thus, reactive oxygen species and adhesion molecules play an important role in the development of inflammatory bowel disease. The present review focuses on the involvement of oxidative stress and adhesion molecules, in particular mucosal addressin cell adhesion molecule-1, in inflammatory bowel disease.
\end{abstract}

Key Words: ROS, oxidative stress, MAdCAM-1, IBD lthough the etiology of inflammatory bowel diseases (IBD)
such as ulcerative colitis (UC) and Crohn's disease (CD)
remains uncertain, the interplay of environmental, genetic and
immunological factors against bacterial flora is believed to
underlie the generation of IBD. (1) Uncontrolled and excessive host
immune responses, during which oxidative stress-like reactive
oxygen species (ROS) and free radicals are produced from inflam-
matory cell infiltrates in the gut mucosa, are known to trigger
mucosal injury and induce inflammation.
IBD is characterized by the extravasation of numerous inflam-
matory cells, including neutrophils and lymphocytes. Adhesion
molecules such as intercellular adhesion molecule 1 (ICAM-1),
vascular cell adhesion molecule-1 (VCAM-1), and mucosal
addressin cell adhesion molecule-1 (MAdCAM-1) mediate a
series of immune responses and gut inflammation. Among the
adhesion molecules that are upregulated in IBD, MAdCAM-1 is
considered to be preeminent for the development of chronic gut
inflammation. MAdCAM-1 expression is induced on the surface
of lymphatic vessels by ROS and by inflammatory cytokines
such as tumor necrotic factor (TNF)- $\alpha$ and interleukin (IL)-1 $\beta$.
MAdCAM-1 has been implicated in the selective recruitment of
lymphocytes to sites of inflammation in the gut. Thus, oxidative
stress and MAdCAM-1 play important roles in IBD development
by mediating the movement and accumulation of lymphocytes
into gut interstitium and by causing mucosal injury.

The present review focuses on the involvement of oxidative stress and MAdCAM-1 during the development of IBD.

\section{Oxidative Stress}

Oxidative stress primarily arises and causes tissue injury when the cytotoxic effects of ROS and free radicals overwhelm elimination of their cytotoxic effects by antioxidants. ROS, which are comprised of singlet oxygen, superoxide anions, hydroxyl radicals, and hydrogen peroxide including free radicals, are all generated as by-products of the normal metabolism of molecular oxygen. A broad definition of ROS includes hydroperoxyl, peroxyl and alkoxyl radicals, hydroperoxide, hypochlorous acid, ozone, nitric monoxide, and nitrogen dioxide. ROS can directly impair any oxidizable molecule.

\section{Oxidative Damage by ROS}

Excessive levels of ROS attack and impair almost all cellular components, including cell membranes, lipids, proteins, enzymes and DNA, and consequently cause apoptotic cell death. Regarding the effect of ROS on the cell membrane, it is known that the polyunsaturated fatty acids in the cell membrane lipid bi-layer have two or more carbon double bonds within their structure susceptible to oxidative attack. ${ }^{(2)}$ Sequential attack against these bonds by hydroxyl radicals $\left({ }^{\circ} \mathrm{OH}\right)$ converts the membrane lipids into oxidized phospholipids (lipid peroxidation). The accumulation of peroxidized lipids accelerates disruption of cell membrane integrity that occurs when the ability of the cell to remove excessive products of hydroxyl radicals and their precursors, in particular the products of hydrogen peroxide $\left(\mathrm{H}_{2} \mathrm{O}_{2}\right)$, fails. This failure and the subsequent increase in ROS results in decreased function of transmembrane enzymes, transporters, receptors and other membrane proteins, which are consequently degraded. ${ }^{(3,4)}$ Moreover, colonic epithelia disintegrate because of the ROS-induced increase in mucosal permeability. ${ }^{(5,6)}$

Next, proteins and enzymes, which are predominant constituents of the cells, are also the target of ROS and oxidative stress. Thus, the $\mathrm{OH}$ radical also attacks, and abrogates many proteins and enzymes. The toxic oxidative effects of ${ }^{\circ} \mathrm{OH}$ include the induction of protein conformational change, which is a major cause of the partial or complete loss of protein function. ${ }^{(7)}$

Peroxynitrite $\left(\mathrm{ONOO}^{-}\right)$is a potent oxidant and nitrating species that is formed from a rapid reaction between the superoxide anion $\left(\mathrm{O}_{2}{ }^{--}\right)$and nitric oxide $(\mathrm{NO}) .^{(8)} \mathrm{ONOO}^{-}$easily crosses biological

*To whom correspondence should be addressed. E-mail: stanida@med.nagoya-cu.ac.jp 
membranes, and, despite a relatively short half-life (within $10 \mathrm{~ms}$ ), it can interact with target molecules in an adjacent cell within one or two cell diameters. ${ }^{(9)}$ Interestingly, exposure to $\mathrm{ONOO}^{-}$promotes the conversion of tyrosine residues into 3-nitrotyrosine, which cannot be readily phosphorylated. $\mathrm{ONOO}^{-}$thus interferes with cellular signaling that is dependent on tyrosine phosphorylation by protein tyrosine kinases. ${ }^{(10)}$ Tyrosine nitration by $\mathrm{ONOO}^{-}$ can either prevent a protein from functioning as the phosphorylated form and/or can mimic the structural change induced by phosphorylation and thereby imitate the consequences of phosphorylation. ${ }^{(11)}$ In contrast to ${ }^{\circ} \mathrm{OH}, \mathrm{ONOO}^{-}$can up- or downregulate signaling cascades by controlling the activities of protein kinases. This control is achieved by nitration of tyrosine residues, thereby resulting in gain- or loss of function of kinase activity. ${ }^{(12)}$

Finally, regarding the effect of ROS on DNA, both nuclear DNA $^{(13)}$ and mitochondrial DNA ${ }^{(14)}$ are also known to be targets of oxidative attack, particularly from ${ }^{\circ} \mathrm{OH}$ and $\mathrm{ONOO}^{-}$, which cause base and sugar hydroxylation ${ }^{(15)}$ as well as breaks in the double strand, leading to adenosine triphosphate depletion, gene mutations and mitochondrial DNA deletions. ${ }^{(16,17)}$ These changes ultimately induce malignant transformation and apoptotic cell death. Thus, oxidative stress thus harms almost all cellular components.

\section{Noxious Involvement of ROS in IBD}

Direct measurement of ROS in cells and tissues is quite difficult because of their short biological half-lives. ${ }^{(18)}$ However, direct quantification of ROS levels in colon biopsy specimens from UC and $C D$ patients using chemiluminescence assays showed that ROS levels in these tissues are considerably increased compared to those in normal mucosa and positively correlate with IBD. ${ }^{(19-22)}$ Mounting evidences indicate that there are increased levels of reactive nitrogen metabolites (RNM) such as NO in the inflamed IBD mucosa based on analysis of nitric oxide synthase activity. ${ }^{(23-26)}$ Thus, increased levels of both ROS and RNM are closely correlated with the clinical development of IBD.

Relationship between Adhesive Molecules and Cytokines, and Inflammatory Cells Infiltration and Immune Responses

The consecutive events involved in the extravasation of inflammatory cells from lymphatics and blood vessels to the extravascular space include the following steps: 1, tethering and rolling of the inflammatory cells on the endothelial cell surface; 2 , firm attachment to endothelial cells followed by transendothelial migration; and 3, migration toward chemoattractants produced in the lamina propria, which is mediated by the interaction between adhesion molecules on the surface of lymphocytes or neutrophils and their receptors on endothelial cells and vice versa. Various cytokines induce the tethering and rolling of neutrophils on vascular endothelial cells through modulation of the interactions between L-selectin and carbohydrate antigen on neutrophils, and P- and E-selectin on endothelial cells. ${ }^{(27-29)}$ On the other hand interactions between adhesion molecules on the surface of lymphocytes and the adhesion molecule MAdCAM-1 on lymphatic endothelial cells are responsible for lymphocyte tethering. ${ }^{(30)}$ At a later stage, neutrophils and lymphocytes strongly adhere to endothelial cells through other adhesion molecules including ICAM-1, VCAM-1 and MAdCAM-1, and consequently transmigrate into lamina propria mucosae. ROS, lipopolysaccharide (LPS) and inflammatory cytokines such as IL-1 $\beta$ and TNF- $\alpha$ induce the translocation of P-selectin, L-selectin and MAdCAM-1 from intracellular locations to the cell surface. Increased surface expression of P-selectin, ICAM, and MAdCAM-1 is observed in the colon mucosa of patients with IBD. ${ }^{(31,32)}$ Interaction between inflammatory cells and endothelial cells through these adhesion molecules is thus involved in the development of IBD.

\section{MAdCAM-1 and Its Receptor, $\alpha 4 \beta 7$ Integrin}

MAdCAM-1 is a $58-66 \mathrm{kDa}$ type 1 transmembrane glycoprotein belonging to the immunoglobulin (Ig) superfamily, which is comprised of two amino-terminal Ig-like domains and shares a conserved amino acid sequence homology with VCAM-1.(33) The interaction of integrin $\alpha 4 \beta 7$ and MAdCAM-1 is involved in cell homing, firm adhesion, and transendothelial cell migration when lymphocytes are recirculated to peripheral lymph nodes under normal conditions and when lymphocytes are recruited to sites of gut inflammation. ${ }^{(30)}$ The homing of murine lymphocytes to intestinal mucosa was first discovered to be mediated by a molecule that bound to Peyer's patches high endothelial venules (HEV). ${ }^{(34)}$ This molecule is known as lymphocyte Peyer's patches HEV adhesion molecule (LPAM)-1 and was ultimately identified as an integrin, which is a heterodimer of $\alpha$ - and $\beta$-subunits. The $\alpha 4$ subunit of murine LPAM-2 has $84 \%$ homology at the amino acid level with the human integrin $\alpha 4$-subunit. ${ }^{(35)}$ An anti-rat $\alpha 4$ blocking antibody inhibited lymphocyte migration to Peyer's patches, indicating that $\alpha 4$ integrin plays an important role in mucosal homing. ${ }^{(36)}$

Initially, the murine integrin $\beta$-subunit was believed to be a novel molecule. However, it is currently known that the human $\beta 7$ integrin subunit is the human homolog of the murine integrin $\beta$ subunit. ${ }^{(37,38)}$

MAdCAM-1 is expressed in Peyer's patches HEV and in mesenteric lymph nodes, intestinal mucosal venules in the lamina propria, and lymphoid follicles in the normal murine gut. MAdCAM-1 directly binds to its receptor, $\alpha 4 \beta 7$ integrin. Blocking antibodies against either $\alpha 4$ - or $\beta 7$-subunits abrogate the binding of lymphocytes to MAdCAM-1 in vivo and in vitro. ${ }^{(39)}$ Therefore, MAdCAM- 1 binds to both $\alpha 4$ - and $\beta 7$-subunits.

\section{IBD and MAdCAM-1}

Under normal conditions, MAdCAM-1 expression is limited to the endothelium of venules within the lamina propria and submucosa, and to the HEVs of Peyer's patches and mesenteric lymph nodes. In mouse models of IBD in which experimental colitis was induced with dextran sulfate sodium (DSS) or trinitrobenzene sulfonic acid (TNB), and also in the inflamed colon of human patients with UC and CD, MAdCAM-1 expression was reported to be increased in the lamina propria and submucosal venules within the inflamed sites of the colon compared to its expression in non-inflamed tissues. ${ }^{(40-42)}$ MAdCAM-1 transcription is activated through translocation of the activated p50/p65 nuclear factor kappa-B (NF- $\kappa \mathrm{B})$ complex into the nucleus following proteosomal degradation of phosphorylated I $\mathrm{B}$ (inhibitor of $\kappa \mathrm{B})$ in response to several cytokines including TNF- $\alpha$ and IL-1 $\beta .^{(43,44)}$ Moreover, experimental studies using a SVEC cell line derived from axillary lymph nodes, and a colon-derived endothelial cell line established from transgenic mice bearing a temperature-sensitive SV40 large T antigen, have shown that TNF- $\alpha$ stimulates MAdCAM-1 expression through activation of tyrosine kinase, p38 and p42/p44 mitogen-activated protein kinase (MAPK), and NF- $\kappa \mathrm{B} /$ poly-ADP ribose polymerase (PARP) signaling cascades. ${ }^{(45,46)}$

The addition of cytochrome P-450 (CYP450) 3A4 inhibitors such as bergamottin and 6',7'-dihydroxybergamottin (DHB) to cultured SVEC endothelial cells demonstrated that these CYP450 inhibitors blocked TNF- $\alpha$-induced MAdCAM-1 expression and lymphocyte adhesion in vitro. ${ }^{(4)}$ Interestingly, our very recent study showed that the angiotensin II type 1 receptor antagonist (AT1R antagonist), candesartan, can be used as a novel therapy for IBD. We demonstrated that this AT1R antagonist blocked intranuclear translocation of the activated p50/p65 NF- $\kappa \mathrm{B}$ complex in a p38 MAPK independent manner and thereby downregulated TNF- $\alpha$-induced MAdCAM- 1 expression, resulting in the amelio- 


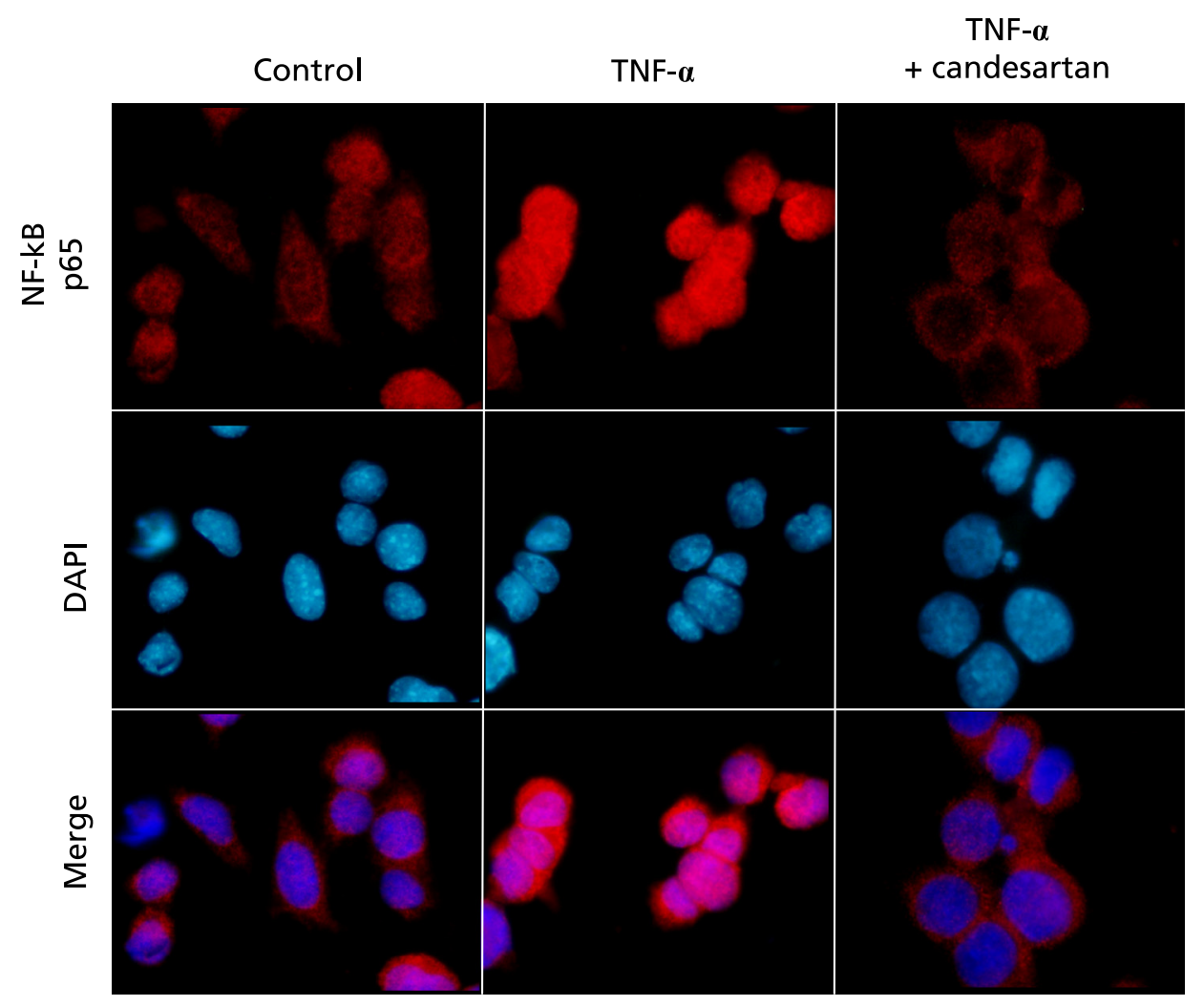

Fig. 1. Localization of NF-KB p65protein in the presence and the absence of Candesartan during TNF- $\alpha$ stimulation. Cells were pretreated with or without Candesartan and then stimulated with TNF- $\alpha$. Immunofluorescent co-staining of NF- $\mathrm{KB}$ p65 protein and cell nuclei stained using DAPI was subsequently performed. Quoted from ref. 48.

ration of colitis (Fig. 1). ${ }^{(48)}$ It has also shown that there is a significant attenuation of MAdCAM-1 expression, inflammatory cell infiltration and mucosal damages during DSS-induced colitis in mice lacking AT1R gene compared to these parameters in wildtype mice. ${ }^{(48,49)}$ This result suggests that TNF- $\alpha$ can induce MAdCAM-1 expression by three different pathways.

Blocking the pathway by which TNF- $\alpha$ induces MAdCAM-1 expression is thus considered to be useful for IBD treatment. Several studies have been carried out to search for potent candidate blockers of TNF- $\alpha$-induced MAdCAM- 1 expression that could be used for IBD treatment. Such candidates include a component present in grapefruit and grapefruit peel oil, its derivatives; bergamottin and DHB, ${ }^{(47)}$ CYP450 inhibitor, troglitazone, ${ }^{(50)}$ which is a $\gamma$-subtype of a peroxisome proliferator-activated receptor (PPAR- $\gamma$ ) ligand that blocks phosphorylation of p65 $\mathrm{NF}-\kappa \mathrm{B}$, and candesartan, ${ }^{(48)}$ which, as mentioned above, is an agent that blocks translocation of the activated p50/p65 NF- $\kappa \mathrm{B}$ complex into the nucleus.

\section{Conclusion and Perspectives}

It has been established that ROS and MAdCAM-1 play a critical role in the development of IBD by mediating enhanced extravasation of lymphocytes. Future development and study of neutralizing or blocking antibodies, and chemicals that target molecules involved in the development of IBD, (Table 1), will ensure that detailed molecular mechanisms that underlie the occurrence and perpetuation of gut inflammation will be elucidated in the future.

\section{Acknowledgments}

Satoshi Tanida, Tsutomu Mizoshita, Takashi Mizushima,
Takaya Shimura, Takeshi Kamiya and Hiromi Kataoka are all members of digestive disease group in Nagoya City University, Department of Gastroenterology and Metabolism and Professor Takashi Joh heads up our department. Makoto Sasaki is one of the members of digestive disease group in Aichi Medical University. We are going forward on the advanced basic researches in order to elucidate how persistent inflammation induces the occurrence of cancer, and how IBD inflammation occurs, and are trying to clarify these difficult problems in the future.

\section{Abbreviations}

IBD inflammatory bowel diseases

UC ulcerative colitis

CD Crohn's disease

ROS reactive oxygen species

ICAM-1 intercellular adhesion molecule 1

VCAM-1 vascular cell adhesion molecule-1

MAdCAM-1 mucosal addressin cell adhesion molecule-1

TNF tumor necrotic factor

IL interleukin

NO nitric oxygen

RNM reactive nitrogen metabolites

LPS lipopolysaccharide

Ig immunoglobulin

HEV high endothelial venules

LPAM lymphocyte Peyer's patches HEV adhesion molecule

DSS dextran sulfate sodium

TNB trinitrobenzene sulfonic acid

NF- $\kappa$ B nuclear factor kappa-B

MAPKs mitogen-activated protein kinases 
Table 1. Therapuetic molecular target for IBD under clinical application and investigation

\begin{tabular}{|c|c|c|c|c|c|}
\hline \multicolumn{2}{|c|}{ molecular targets and name } & $\begin{array}{c}\text { drug product } \\
\text { antibody }\end{array}$ & $\begin{array}{l}\text { disease } \\
\text { UC, CD }\end{array}$ & $\begin{array}{c}\text { efficacy for human } \\
\text { effective }\end{array}$ & $\begin{array}{c}\text { references } \\
51,52,53\end{array}$ \\
\hline TNF- $\alpha$ & $\begin{array}{l}\text { Infliximab } \\
\text { Adalimumab } \\
\text { Certolizumab pegol } \\
\text { Etanercept } \\
\text { Golimumab }\end{array}$ & $\begin{array}{l}\text { antibody } \\
\text { antibody } \\
\text { antibody } \\
\text { antibody } \\
\text { antibody }\end{array}$ & $\begin{array}{l}\text { UC, CD } \\
\text { UC, CD } \\
C D \\
C D \\
U C, C D\end{array}$ & $\begin{array}{c}\text { effective } \\
\text { effective } \\
\text { effective } \\
\text { invalid } \\
\text { effective }\end{array}$ & $\begin{array}{c}51,52,53 \\
54,55 \\
56 \\
57 \\
58\end{array}$ \\
\hline IFN- $\gamma$ & Fontlizumab & antibody & $C D$ & invalid & 59 \\
\hline IL-6 receptor & Tocilizumab & antibody & $C D$ & effective $\#$ & 60 \\
\hline $\mathrm{IL}-12 / 23$ & Ustekinumab & antibody & $C D$ & effective \# & 61 \\
\hline CD20 & Rituximab & antibody & UC, CD & underway & \\
\hline$\alpha 1 \beta 1$ integrin & no name & antibody & DSS colitis & N/A for human & 62 \\
\hline$\alpha 4$ integrin & $\begin{array}{l}\text { AJM-300 } \\
\text { Natalizumab }\end{array}$ & $\begin{array}{l}\text { chemical } \\
\text { antibody }\end{array}$ & $\begin{array}{c}C D \\
U C, C D\end{array}$ & $\begin{array}{l}\text { effective \# } \\
\text { effective }\end{array}$ & $\begin{array}{l}63 \\
64\end{array}$ \\
\hline$\alpha 4 \beta 7$ integrin & Vedolizumab & antibody & UC, CD & effective & 65,66 \\
\hline$\beta 7$ integrin & rhuMab b7 & antibody & UC & underway & \\
\hline PSGL-1 & no name & antibody & DSS colitis & N/A for human & 67 \\
\hline ICAM-1 & no name & antibody & DSS colitis & N/A for human & 68 \\
\hline VCAM-1 & no name & antibody & DSS colitis & N/A for human & 69 \\
\hline MAdCAM-1 & PF-00547659 & antibody & UC & underway & \\
\hline
\end{tabular}

\#: result in phase II trial, N/A: not applicable, DSScolitis: dextran sodium sulfate-induced experimental colitis

PSGL-1: P-selectin glycoprotein ligand-1

PARP

CYP450

poly-ADP ribose polymerase

$\mathrm{DHB}$

cytochrome P-450

6',7'-dihydroxybergamottin
AT1R PPAR- $\gamma$ angiotensin II type 1 receptor $\gamma$-subtype of peroxisome proliferator-activated receptor

\section{References}

1 Hoffmann JC, Pawlowski NN, Kühl AA, Höhne W, Zeitz M. Animal models of inflammatory bowel disease: an overview. Pathobiology 2002; 70: 121130.

2 Gutteridge JM. Lipid peroxidation and antioxidants as biomarkers of tissue damage. Clin Chem 1995; 41: 1819-1828.

3 Ohyashiki T, Ohtsuka T, Mohri T. A change in the lipid fluidity of the porcine intestinal brush-border membranes by lipid peroxidation. Studies using pyrene and fluorescent stearic acid derivatives. Biochim Biophys Acta 1986; 861: 311-318.

4 Jourd'Heuil D, Vaananen P, Meddings JB. Lipid peroxidation of the brushborder membrane: membrane physical properties and glucose transport. Am J Physiol 1993; 264: G1009-G1015.

5 Riedle B, Kerjaschk D. Reactive oxygen species cause direct damage of Engelbreth-Holm-Swarm matrix. Am J Pathol 1997; 151: 215-231.

6 Rao RK, Baker RD, Baker SS, Gupta A, Holycross M. Oxidant-induced disruption of the intestinal epithelial barrier function: role of protein tyrosine phosphorylation. Am J Physiol 1997; 273: G812-G823.

7 Stadtman ER, Berlett BS. Reactive oxygen-mediated protein oxidation in aging and disease. Chem Res Toxicol 1997; 10: 485-494.

8 Pacher P, Beckman JS, Liaudet L. Nitric oxide and peroxynitrite in health and disease. Physiol Rev 2007; 87: 315-424.

9 Szabó C, Ischiropoulos H, Radi R. Peroxynitrite: biochemistry, pathophysiology and development of therapeutics. Nat Rev Drug Discov 2007; 6: $662-680$.

10 Kong SK, Yim MB, Stadtman ER, Chock PB. Peroxynitrite disables the tyrosine phosphorylation regulatory mechanism: lymphocyte-specific tyrosine kinase fails to phosphorylate nitrated cdc2(6-20)NH2 peptide. Proc Natl Acad Sci USA 1996; 93: 3377-3382.

11 MacMillan-Crow LA, Greendorfer JS, Vickers SM, Thompson JA. Tyrosine nitration of c-SRC tyrosine kinase in human pancreatic ductal adenocarcinoma. Arch Biochem Biophys 2000; 377: 350-356.

12 Peluffo G, Radi R. Biochemistry of protein tyrosine nitration in cardiovascular pathology. Cardiovasc Res 2007; 75: 291-302.
13 Henle ES, Linn S. Formation, prevention, and repair of DNA damage by iron/hydrogen peroxide. J Biol Chem 1997; 272: 19095-19098.

14 Yakes FM, Van Houten B. Mitochondrial DNA damage is more extensive and persists longer than nuclear DNA damage in human cells following oxidative stress. Proc Natl Acad Sci USA 1997; 94: 514-519.

15 Dizdaroglu M, Jaruga P, Birincioglu M, Rodriguez H. Free radical-induced damage to DNA: mechanisms and measurement. Free Radic Biol Med 2002; 32: $1102-1115$.

16 Wanrooij S, Goffart S, Pohjoismäki JL, Yasukawa T, Spelbrink JN. Expression of catalytic mutants of the mtDNA helicase Twinkle and polymerase POLG causes distinct replication stalling phenotypes. Nucleic Acids Res 2007; 35: 3238-3251.

17 Lieber MR, Karanjawala ZE. Ageing, repetitive genomes and DNA damage. Nat Rev Mol Cell Biol 2004; 5: 69-75.

18 Rumley AG, Paterson JR. Analytical aspects of antioxidants and free radical activity in clinical biochemistry. Ann Clin Biochem 1998; 35: 181-200.

19 Keshavarzian A, Sedghi S, Kanofsky J, and et al. Excessive production of reactive oxygen metabolites by inflamed colon: analysis by chemiluminescence probe. Gastroenterology 1992; 103: 177-185.

20 Simmonds NJ, Allen RE, Stevens TR, Van Someren RN, Blake DR, Rampton DS. Chemiluminescence assay of mucosal reactive oxygen metabolites in inflammatory bowel disease. Gastroenterology 1992; 103: 186-196.

21 Sedghi S, Fields JZ, Klamut M, and et al. Increased production of luminol enhanced chemiluminescence by the inflamed colonic mucosa in patients with ulcerative colitis. Gut 1993; 34: 1191-1197.

22 Naito Y, Takagi T, Yoshikawa T. Neutrophil-dependent oxidative stress in ulcerative colitis. J Clin Biochem Nutr 2007; 41: 18-26.

23 Boughton-Smith NK, Evans SM, Hawkey CJ, and et al. Nitric oxide synthase activity in ulcerative colitis and Crohn's disease. Lancet 1993; 342: 338-340.

24 Godkin AJ, De Belder AJ, Villa L, and et al. Expression of nitric oxide synthase in ulcerative colitis. Eur J Clin Invest 1996; 26: 867-872.

25 Singer II, Kawka DW, Scott S, and et al. Expression of inducible nitric oxide synthase and nitrotyrosine in colonic epithelium in inflammatory bowel disease. 
Gastroenterology 1996; 111: 871-885.

26 Sasaki M, Joh T. Oxidative stress and ischemia-reperfusion injury in gastrointestinal tract and antioxidant, protective agents. J Clin Biochem Nutr 2007; 40: $1-12$.

27 Kokura S, Wolf RE, Yoshikawa T, Granger DN, Aw TY. Molecular mechanisms of neutrophil-endothelial cell adhesion induced by redox imbalance. Circ Res 1999; 84: 516-524.

28 Yoshida N, Yamaguchi T, Nakagawa S, Nakamura Y, Naito Y, Yoshikawa T. Role of P-selectin and intercellular adhesion molecule-1 in TNB-induced colitis in rats. Digestion 2001; 63: 81-86.

29 Nishimura T, Andoh A, Hashimoto T, Kobori A, Tsujikawa T, Fujiyama Y. Cellobiose prevents the development of dextran sulfate sodium (DSS)induced experimental colitis. J Clin Biochem Nutr 2010; 46: 105-110.

30 Berlin C, Berg EL, Briskin MJ, and et al. Alpha 4 beta 7 integrin mediates lymphocyte binding to the mucosal vascular addressin MAdCAM-1. Cell 1993; 74: 185-195.

31 Nakamura S, Ohtani H, Watanabe Y, and et al. In situ expression of the cell adhesion molecules in inflammatory bowel disease. Evidence of immunologic activation of vascular endothelial cells. Lab Invest 1993; 69: 77-85.

32 Schürmann GM, Bishop AE, Facer P, and et al. Increased expression of cell adhesion molecule P-selectin in active inflammatory bowel disease. Gut 1995; 36: 411-418.

33 Briskin MJ, McEvoy LM, Butcher EC. MAdCAM-1 has homology to immunoglobulin and mucin-like adhesion receptors and to $\operatorname{IgA} 1$. Nature 1993; 363: 461-464.

34 Holzmann B, Weissman IL. Peyer's patch-specific lymphocyte homing receptors consist of a VLA-4-like alpha chain associated with either of two integrin beta chains, one of which is novel. EMBOJ 1989; 8: 1735-1741.

35 Neuhaus H, Hu MC, Hemler ME, Takada Y, Holzmann B, Weissman IL. Cloning and expression of cDNAs for the alpha subunit of the murine lymphocyte-Peyer's patch adhesion molecule. J Cell Biol 1991; 115: 11491158.

36 Issekutz TB. Inhibition of in vivo lymphocyte migration to inflammation and homing to lymphoid tissues by the TA-2 monoclonal antibody. A likely role for VLA-4 in vivo. J Immunol 1991; 147: 4178-4184.

37 Yuan QA, Jiang WM, Krissansen GW, Watson JD. Cloning and sequence analysis of a novel beta 2-related integrin transcript from $\mathrm{T}$ lymphocytes: homology of integrin cysteine-rich repeats to domain III of laminin B chains. Int Immunol 1990; 2: 1097-1108.

$38 \mathrm{Hu}$ MC, Crowe DT, Weissman IL, Holzmann B. Cloning and expression of mouse integrin beta $\mathrm{p}$ (beta 7): a functional role in Peyer's patch-specific lymphocyte homing. Proc Natl Acad Sci USA 1992; 89: 8254-8258.

39 Erle DJ, Briskin MJ, Butcher EC, Garcia-Pardo A, Lazarovits AI, Tidswell M. Expression and function of the MAdCAM-1 receptor, integrin alpha 4 beta 7, on human leukocytes. J Immunol 1994; 153: 517-528.

40 Viney JL, Jones S, Chiu HH, and et al. Mucosal addressin cell adhesion molecule-1: a structural and functional analysis demarcates the integrin binding motif. J Immunol 1996; 157: 2488-2497.

41 Briskin M, Winsor-Hines D, Shyjan A, and et al. Human mucosal addressin cell adhesion molecule-1 is preferentially expressed in intestinal tract and associated lymphoid tissue. Am J Pathol 1997; 151: 97-110.

42 Souza HS, Elia CC, Spencer J, MacDonald TT. Expression of lymphocyteendothelial receptor-ligand pairs, alpha4beta7/MAdCAM-1 and OX40/OX40 ligand in the colon and jejunum of patients with inflammatory bowel disease. Gut 1999; 45: 856-863.

43 Takeuchi M, Baichwal VR. Induction of the gene encoding mucosal vascular addressin cell adhesion molecule 1 by tumor necrosis factor alpha is mediated by NF-kappa B proteins. Proc Natl Acad Sci USA 1995; 92: 3561-3565.

44 Collins T, Read MA, Neish AS, Whitley MZ, Thanos D, Maniatis T. Transcriptional regulation of endothelial cell adhesion molecules: NF-kappa B and cytokine-inducible enhancers. FASEB J 1995; 9: 899-909.

45 Oshima T, Pavlick KP, Laroux FS, and et al. Regulation and distribution of MAdCAM-1 in endothelial cells in vitro. Am J Physiol Cell Physiol 2001; 281: C1096-C1105.

46 Ando T, Jordan P, Wang Y, and et al. MAdCAM-1 expression and regulation in murine colonic endothelial cells in vitro. Inflamm Bowel Dis 2005; 11: 258-264.

47 Sasaki M, Elrod JW, Jordan P, and et al. CYP450 dietary inhibitors attenuate TNF-alpha-stimulated endothelial molecule expression and leukocyte adhe- sion. Am J Physiol Cell Physiol 2004; 286: C931-C939.

48 Mizushima T, Sasaki M, Ando T, and et al. Blockage of angiotensin II type 1 receptor regulates TNF-alpha-induced MAdCAM-1 expression via inhibition of NF-kappaB translocation to the nucleus and ameliorates colitis. $\mathrm{Am} \mathrm{J}$ Physiol Gastrointest Liver Physiol 2010; 298: G255-G266.

49 Katada K, Yoshida N, Suzuki T, and et al. Dextran sulfate sodium-induced acute colonic inflammation in angiotensin II type 1a receptor deficient mice. Inflamm Res 2008; 57: 84-91.

50 Sasaki M, Jordan P, Welbourne T, and et al. Troglitazone, a PPAR-gamma activator prevents endothelial cell adhesion molecule expression and lymphocyte adhesion mediated by TNF-alpha. BMC Physiol 2005; 5: 3.

51 Hanauer SB, Feagan BG, Lichtenstein GR, and et al. Maintenance infliximab for Crohn's disease: the ACCENT I randomised trial. Lancet 2002; 359: 1541-1549.

52 Sands BE, Anderson FH, Bernstein $\mathrm{CN}$, and et al. Infliximab maintenance therapy for fistulizing Crohn's disease. N Engl J Med 2004; 350: 876-885.

53 Rutgeerts P, Sandborn WJ, Feagan BG, and et al. Infliximab for induction and maintenance therapy for ulcerative colitis. $N$ Engl J Med 2005; 353: 2462-2476.

54 Hanauer SB, Sandborn WJ, Rutgeerts P, and et al. Human anti-tumor necrosis factor monoclonal antibody (adalimumab) in Crohn's disease: the CLASSIC-I trial. Gastroenterology 2006; 130: 323-333.

55 Sandborn WJ, Hanauer SB, Rutgeerts $\mathrm{P}$, and et al. Adalimumab for maintenance treatment of Crohn's disease: results of the CLASSIC II trial. Gut 2007; 56: $1232-1239$.

56 Sandborn WJ, Feagan BG, Stoinov S, and et al. Certolizumab pegol for the treatment of Crohn's disease. N Engl J Med 2007; 357: 228-238.

57 Marzo-Ortega H, McGonagle D, O’Connor P, Emery P. Efficacy of etanercept for treatment of Crohn's related spondyloarthritis but not colitis. Ann Rheum Dis 2003; 62: 74-76.

58 Hutas G. Golimumab, a fully human monoclonal antibody against TNFalpha. Curr Opin Mol Ther 2008; 10: 393-406.

59 Reinisch W, Hommes DW, Van Assche G. A dose escalating, placebo controlled, double blind, single dose and multidose, safety and tolerability study of fontolizumab, a humanised anti-interferon gamma antibody, in patients with moderate to severe Crohn's disease. Gut 2006; 55: 1138-1144.

60 Ito H, Takazoe M, Fukuda Y, and et al. A pilot randomized trial of a human anti-interleukin-6 receptor monoclonal antibody in active Crohn's disease. Gastroenterology 2004; 126: 989-996.

61 Sandborn WJ, Feagan BG, Fedorak RN, and et al. A randomized trial of Ustekinumab, a human interleukin-12/23 monoclonal antibody, in patients with moderate-to-severe Crohn's disease. Gastroenterology 2008; 135: 1130 1141.

62 Krieglstein CF, Cerwinka WH, Sprague AG, and et al. Collagen-binding integrin alpha1betal regulates intestinal inflammation in experimental colitis J Clin Invest 2002; 110: 1773-1782.

63 Takazoe M, Watanabe M, Kawaguchi T, and et al. Oral alpha-4 integrin Inhibitor (AJM300) in patients with active Crohn's disease: a randomized, double-blind, placebo-controlled trial. Gastroenterology 2009; 136 Suppl 1: 1240 .

64 Sandborn WJ, Colombel JF, Enns R, and et al. Natalizumab induction and maintenance therapy for Crohn's disease. N Engl J Med 2005; 353: 1912 1925.

65 Feagan BG, Greenberg GR, Wild G, and et al. Treatment of ulcerative colitis with a humanized antibody to the alpha4beta7 integrin. $N$ Engl J Med 2005; 352: 2499-2507.

66 Feagan BG, Greenberg GR, Wild G, and et al. Treatment of active Crohn's disease with MLN0002, a humanized antibody to the alpha4beta7 integrin. Clin Gastroenterol Hepatol 2008; 6: 1370-1377.

67 Rijcken EM, Laukoetter MG, Anthoni C, and et al. Immunoblockade of PSGL-1 attenuates established experimental murine colitis by reduction of leukocyte rolling. Am J Physiol Gastrointest Liver Physiol 2004; 287: G115G124.

68 Taniguchi T, Tsukada H, Nakamura H, and et al. Effects of the anti-ICAM-1 monoclonal antibody on dextran sodium sulphate-induced colitis in rats. $J$ Gastroenterol Hepatol 1998; 13: 945-949.

69 Soriano A, Salas A, Sans M, and et al. VCAM-1, but not ICAM-1 or MAdCAM-1, immunoblockade ameliorates DSS-induced colitis in mice. Lab Invest 2000; 80: 1541-1551. 